\title{
Interactive comment on "Implementation of aerosol-cloud interactions in the regional atmosphere-aerosol model COSMO-MUSCAT and evaluation using satellite data" by Dipu Sudhakar
} et al.

\author{
A. Kerkweg \\ kerkweg@uni-bonn.de
}

Received and published: 13 September 2016

Dear authors,

In my role as Executive editor of GMD, I would like to bring to your attention our Editorial version 1.1:

http://www.geosci-model-dev.net/8/3487/2015/gmd-8-3487-2015.html

This highlights some requirements of papers published in GMD, which is also available on the GMD website in the 'Manuscript Types' section:

Printer-friendly version

Discussion paper 
http://www.geoscientific-model-development.net/submission/manuscript_types.html

In particular, please note that for your paper, the following requirement has not been met in the Discussions paper:

- "The main paper must give the model name and version number (or other unique identifier) in the title."

Please add the version numbers for COSMO and MUSCAT or for COSMO-MUSCAT (depending on your versioning system) in the title upon your revised submission to GMD.

Yours,

Astrid Kerkweg

Interactive comment on Geosci. Model Dev. Discuss., doi:10.5194/gmd-2016-186, 2016. 